\title{
Tempe and Soybean var. Grobogan-Indonesia IncreasedThe Number of Osteoblasts and Osteocytes, Inhibited Osteoclast Damage in The Tibia Bone of Rats
}

\author{
Tutik Wresdiyati ${ }^{1 *}$, Alamsah Firdaus $^{1}$, Made Astawan $^{2}$ \\ ${ }^{1}$ Department of Anatomy, Physiology and Pharmacology, Faculty of Veterinary Medicine, Bogor Agricultural University, IPB Darmaga \\ Campus-Bogor, Indonesia \\ ${ }^{2}$ Department of Food Science and Technology, Faculty of Agricultural Technology, Bogor Agricultural University, IPB Darmaga \\ Campus-Bogor, Indonesia
}

\section{ARTICLE INFO}

Article history:

Received September 24, 2018

Received in revised form December 15, 2020

Accepted January 5, 2021

KEYWORDS:

Isoflavone,

osteoblast,

osteoclast,

osteocyte,

tempe

\begin{abstract}
Tempe, an Indonesian traditional food, is a product of processed soybeans by fermentation. Both tempe and soybeans contain a variety of nutrients, such as isoflavone, $\mathrm{Ca}, \mathrm{P}$, and $\mathrm{Mg}$ that are important for bone health. This study aimed to observe the influence of Indonesian var. Grobogan tempe flour and soybean flour on the profile of osteoblasts, osteocytes, and osteoclasts in the tibia bone of rats. The rats were divided into five groups; casein, tempe flour $10 \%$, tempe flour $20 \%$, boiled soybean flour $10 \%$, and boiled soybean flour $20 \%$ groups. The treatment was conducted for 90 days. The results showed that the treatment using tempe flour and soybean flour increased the number of osteoblasts and osteocytes significantly compared to the casein group. Tempe flour $20 \%$ showed the best result. In addition, the number of osteoclasts in the tibia bone of rats that were treated with tempe flour and soybean flour were smaller than that of negative control group. The treatment using soybean flour $(10 \%$ and $20 \%)$ or tempe flour $(10 \%$ and $20 \%)$ decreased the number of osteoclasts in the tibia bone of rats. It is suggested that both tempe and soybeans can be utilized for osteoporosis prevention.
\end{abstract}

\section{Introduction}

Soy is a leguminous seasonal crop that contains various nutrients such as protein, fat, vitamins, and minerals. The Indonesian local soybean var. Grobogan is a superior variety which has a heavy bean weight and high protein content, around $40-44 \%$ (Astawan et al. 2020a).

In Indonesia, soybeans are used as the basic ingredient for various food products such as tempe, tauco, soy sauce, et cetera. Tempe is a well-known traditional Indonesian food. Tempe is made from soybeans fermented using Rhizopus sp. (Kadar et al. 2020). Tempe is a source of protein and minerals. The calcium and phosphorous content per $100 \mathrm{~g}$ tempe is $347 \mathrm{mg}$ and $724 \mathrm{mg}$, respectively (Astawan et al. 2020b). The high calcium and phosphorous content in tempe would increase the availability of the two minerals in the body and would be beneficial

\footnotetext{
* Corresponding Author

E-mail Address: tutikwr@apps.ipb.ac.id
}

in bone growth and development. In addition to being a source of nutrients, tempe is also the only plant-based potential vitamin B12 source. Tempe is also known to contain isoflavone compounds in the form of aglycone which are more readily absorbed (Rachmawati et al. 2021).

Optimum utilization of tempe and efforts to make tempe more popular with the public are done through diversification of tempe products. One form of tempe diversification is by processing tempe into tempe flour. Tempe in the form of flour is more versatile in its use and improves its shelf life (Astawan et al. 2020c). Puteri et al. (2018) also stated that the main issue in tempe is its relatively short shelf life. Therefore, processing it into flour would be an alternative to lengthen its shelf life and increase its uses.

Calcium (Ca) and phosphorous (P) are essential minerals that are very much needed by the body. These minerals, especially calcium, have very important roles in a number of bodily functions such as muscle contractions, nerve impulses, and bone formation. According to Neve et al. (2010) and Bhattarai et al. 
(2020), the bone formation rate by osteoblast cells is influenced by these factors: the availability of calcium, vitamin-D, and the hormone estrogen. The source of minerals such as calcium and phosphorous could be animal or plant-based foods. Astawan et al. (2020b) reported that the bioavailability of the mineral calcium from the consumption of plantbased foods (boiled soybean flour and tempe flour) was not significantly different from that come from animal-based food (casein).

The various nutrients contained in both soybeans and tempe would of course be beneficial for the body. This study aimed to analyze the effect of the administration of tempe flour and boiled soybean flour var. Grobogan on the growth of rats' tibia bone by observing the numbers of osteoblasts, osteocytes, and osteoclasts formed. Tempe flour and boiled soybean flour var. Grobogan was expected to have a positive effect on bone growth in the effort to prevent and overcome osteoporosis and various bone abnormalities.

\section{Materials and Methods}

\subsection{Chemicals and Materials}

Tempe, soybean var. Grobogan from Indonesia, casein, drinking water, physiological $\mathrm{NaCl}$, ketamine, xylazine, Bouin solution, distilled water, $25 \% \mathrm{HCl}$, alcohol, xylol, paraffin, entelan ${ }^{\circledR}$ and Hematoxylin and Eosin staining. All the chemicals used in the assay were analytical grade.

\subsection{The Production of Tempe Flour and Soybean Flour}

The tempe was made from the fermentation of soybean var. Grobogan using Rhizopus sp. at Rumah Tempe Indonesia. Then the tempe and boiled soybean were made into tempe flour and soybean flour in the Laboratory of Food Biochemistry, Department of Food Science and Technology, Faculty of Agricultural Technology, Bogor Agricultural University.

\subsection{Preparation and Treatment of Test Animals}

This study used four-week-old male SpragueDawley white rats. The lab rats were adapted first for 3 days by giving them standard casein feed and drinking water ad libitum. The number of rats used was 25, divided into five treatment groups. Each treatment group consisted of five rats. Each group was given treatment feed (AOAC 1995) which contained different protein sources (Table 1) for 90 days. This research procedure had been approved via ethical clearance letter number 146-2019 from the Ethical Committee of Bogor Agricultural University.

\subsection{Sampling and Bone Tissue Processing}

The tibia was prepared and sampled after the rats were anesthetized using ketamine and xylazine (Sabri 2011). The tibia was then fixated using Bouin solution and decalcified using $25 \% \mathrm{HCl}$ solution. After the bone was softened, the bone was sliced and embedded using the standard method using paraffin. The bone block was sliced using a microtome and the bone tissues were stained using hematoxylin and eosin ( $\mathrm{H}$ and $\mathrm{E})$.

\subsection{Osteoblast, Osteocyte, and Osteoclast Counting}

Identification of osteoblasts, osteocytes, and osteoclasts was done under a light microscope (Olympus CH20). The number of osteoblasts, osteocytes, and osteoclasts were counted using the software ImageJ in ten views per slide. The results were then analyzed using the software SPSS 16 using

Table 1. Composition of experimental diets (percent of weight) for treated rats

\begin{tabular}{lccccccc}
\hline \multirow{2}{*}{ Treatments } & \multicolumn{3}{c}{ Ingredient (\%) } \\
\cline { 2 - 7 } & Sample & Corn oil & $\begin{array}{c}\text { Mineral } \\
\text { mixture }\end{array}$ & $\begin{array}{c}\text { Vitamin } \\
\text { mixture }\end{array}$ & CMC & Water & Corn starch \\
\hline Casein 10\%* & 11.2 & 8.0 & 4.9 & 1.0 & 0.9 & 3.9 & 70.1 \\
Tempe flour 10\%** & 19.3 & 3.1 & 4.6 & 1.0 & 0.0 & 4.2 & 67.8 \\
Tempe flour 20\%** & 38.6 & - & 4.3 & 1.0 & 0.0 & 3.3 & 52.8 \\
Boiled soybean flour 10\%*** & 19.6 & 3.0 & 4.5 & 1.0 & 0.0 & 3.9 & 68.0 \\
Boiled soybean flour 20\%**** & 39.2 & 0.0 & 3.9 & 1.0 & 0.0 & 2.8 & 53.1
\end{tabular}

* $10 \%$ protein in the diet came from casein

** $10 \%$ protein in the diet came from tempe flour

$* * * 20 \%$ protein in the diet came from tempe flour

**** $10 \%$ protein in the diet came from boiled soybean flour

$* * * * * 20 \%$ protein in the diet came from boiled soybean flour 
the one-way ANOVA method. If there was a significant difference $(p<0.05)$ or a very significant difference $(p<0.01)$, the analysis was followed by Duncan's test.

\section{Results}

\subsection{The Number of Osteoblasts and Osteocytes}

The results of $\mathrm{H}$ and $\mathrm{E}$ staining of cross-section slices of the treatment rats' tibia revealed that the osteoblasts and osteocytes were within the compact bone area. The osteoblasts were in the periphery of bone on the inside of the periosteum, whereas the osteocytes were in the middle of the bone mass (Figure 1).

Tempe flour (20\%) treated group demonstrated very significantly $(p<0.01)$ the highest number of osteoblasts compared to the other groups. Tempe flour (10\%) treated group demonstrated a very significantly higher $(\mathrm{p}<0.01)$ number of osteoblasts than casein treated group. On the other hand, casein treated group demonstrated a number of osteoblasts that was not significantly different $(p>0.01)$ from boiled soybean flour (10\% and 20\%) treated groups (Table 2).

The number of osteocytes in tempe flour (20\%) treated group was also the significantly highest $(p<0.01)$ compared to the other groups, followed by the number of osteocytes in tempe flour (10\%) treated group. The number of osteocytes in boiled soybean flour $10 \%$ and $20 \%$ treated groups was not significantly different; both were lower than the number of osteocytes in tempe flour (10\%) treated group. The number of osteocytes in casein treated group was very significantly the lowest $(\mathrm{p}<0.01)$ in comparison to the other groups (Table 2).

\subsection{The Number of Osteoclasts}

The results of the hematoxylin-eosin staining of the reconstruction area in the rats' tibia showed the presence of osteoclasts (Figure 2). The results of statistical analysis of the number of osteoclasts in five views at a magnification of $100 \mathrm{x}$ in the tibia of rats in all the groups are presented in Table 3.

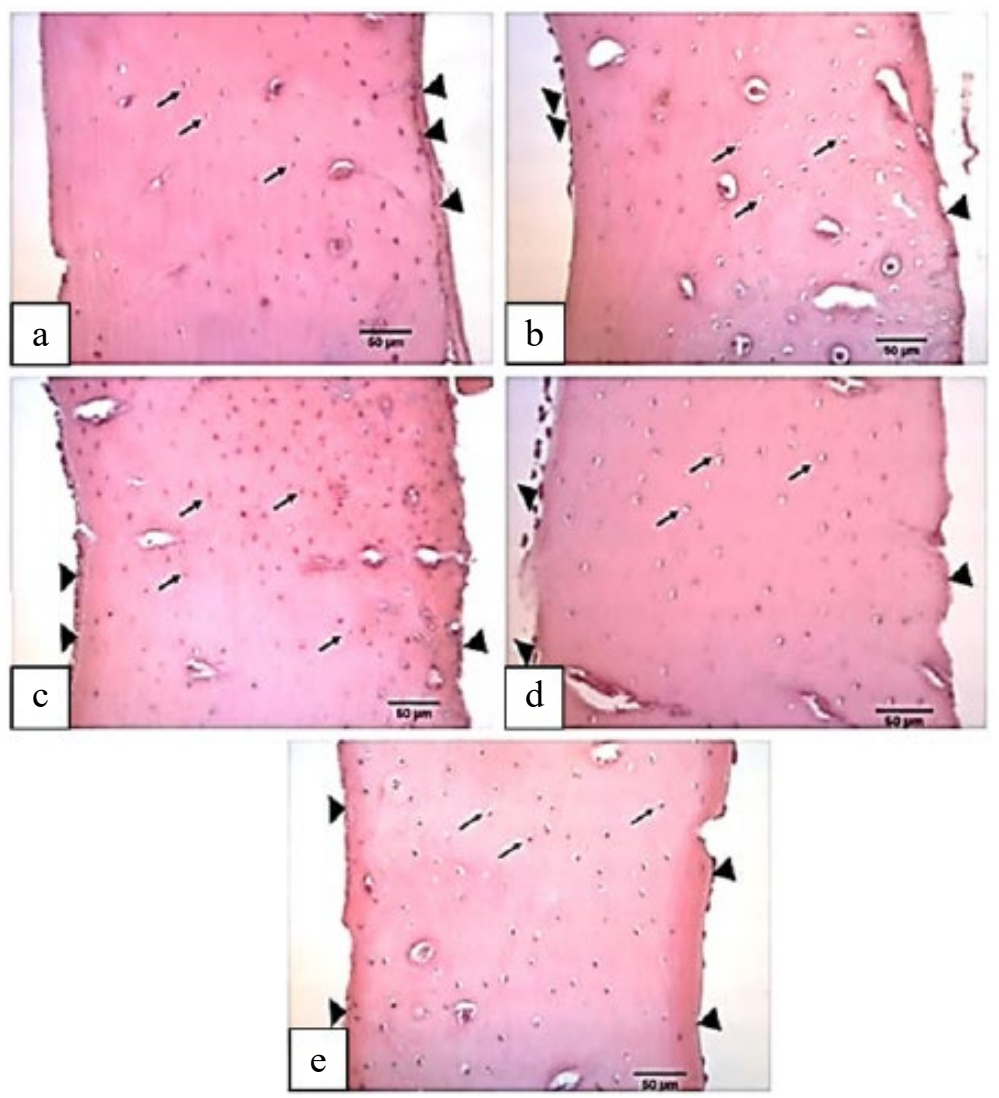

Figure 1. The photomicrograph of osteoblasts (arrow heads) and osteocytes (arrows) in the tibia of the experimental rats. $\mathrm{a}=$ casein $(10 \%), \mathrm{b}=$ tempe flour from soybeans var. Grobogan $(10 \%), \mathrm{c}=$ tempe flour from soybeans var. Grobogan (20\%), d = boiled soybean flour var. Grobogan (10\%), and e = boiled soybean flour var. Grobogan (20\%) 
Table 2. The numbers of osteoblasts and osteocytes per view (100x magnification)

\begin{tabular}{lccc}
\hline Treatment group & Number of osteoblasts & Number of osteocytec & $\begin{array}{l}\text { The sum of osteoblasts } \\
\text { and osteocytes }\end{array}$ \\
\hline Casein & $18.80 \pm 1.31^{\mathrm{a}}$ & $91.90 \pm 1.79^{\mathrm{a}}$ & $110.70 \pm 2.65^{\mathrm{a}}$ \\
Tempe flour 10\% & $23.97 \pm 6.55^{\mathrm{b}}$ & $140.63 \pm 2.65^{\mathrm{c}}$ & $164.60 \pm 6.01^{\mathrm{c}}$ \\
Tempe flour 20\% & $28.73 \pm 4.14^{\mathrm{c}}$ & $144.73 \pm 3.44^{\mathrm{d}}$ & $173.47 \pm 3.34^{\mathrm{d}}$ \\
Boiled soybean flour 10\% & $21.80 \pm 2.41^{\mathrm{a}}$ & $120.87 \pm 1.09^{\mathrm{b}}$ & $142.67 \pm 2.89^{\mathrm{b}}$ \\
Boiled soybean flour 20\% & $22.47 \pm 4.63^{\mathrm{b}}$ & $117.97 \pm 3.69^{\mathrm{b}}$ & $140.43 \pm 6.44^{\mathrm{b}}$ \\
\hline
\end{tabular}

Different letters in the same column show a very significant difference $(\mathrm{p}<0.01)$ based on Duncan's test
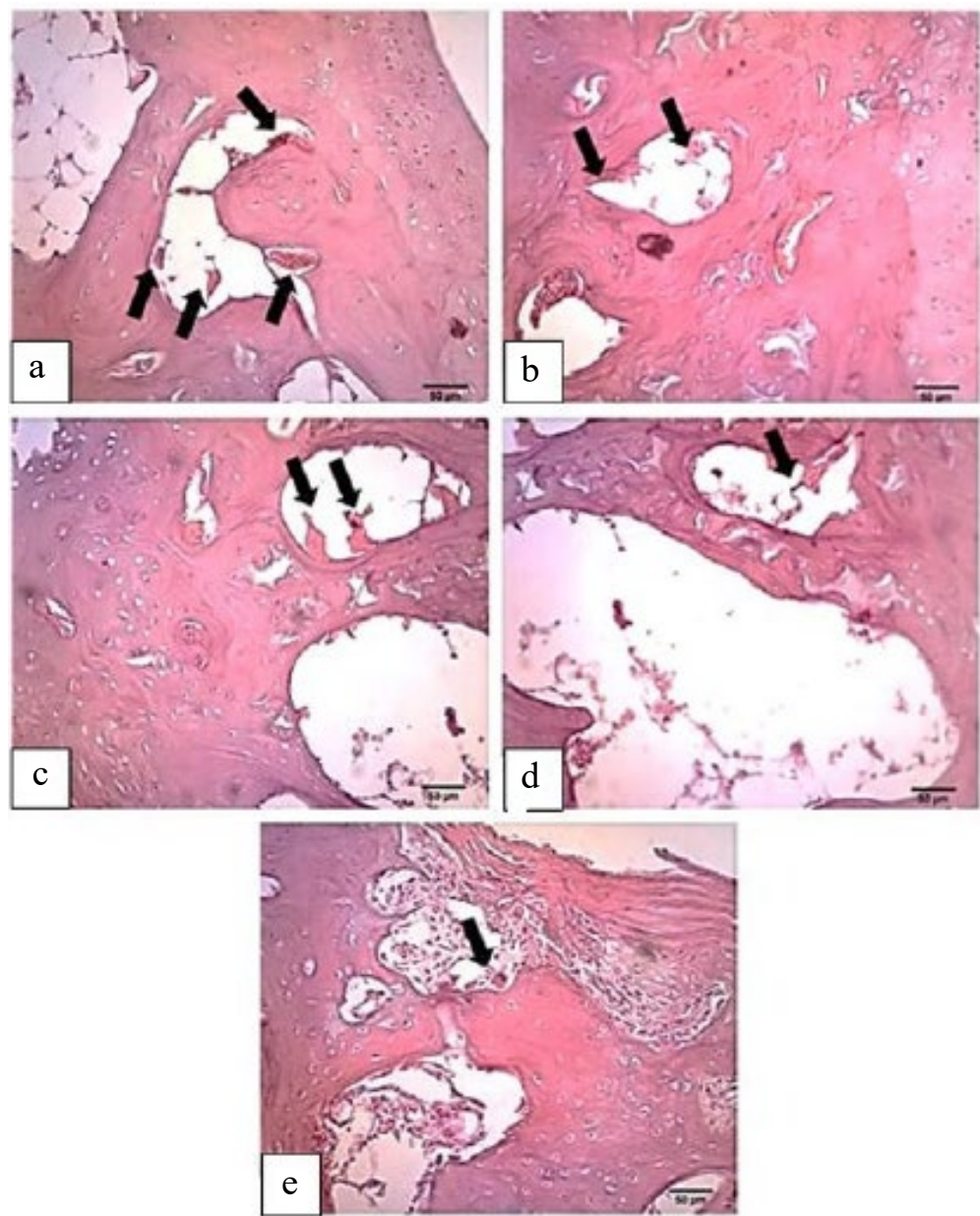

Figure 2. The photomicrograph of osteoclasts (arrows). $\mathrm{a}=$ casein $(10 \%), \mathrm{b}=$ tempe flour from soybeans var. Grobogan (10\%), $\mathrm{c}=$ tempe flour from soybeans var. Grobogan $(20 \%), d=$ boiled soybean flour var. Grobogan (10\%), and $\mathrm{e}=$ boiled soybean flour var. Grobogan (20\%)

Very significantly $(\mathrm{p}<0.01)$, casein treated group had the highest number of osteoclasts compared to the other treatment groups. This result demonstrated that all the treatments, both the administration of tempe flour and boiled soybean flour var. Grobogan could result in a fewer number of osteoclasts than the administration of casein. Tempe flour (10\%) treated group revealed a number of osteoclasts was not significantly different
( $p>0.01$ ) from tempe flour (20\%) dan boiled soybean flour (10\%) groups, but was very significantly higher $(p<0.01)$ than the number of osteoclasts in boiled soybean flour (20\%) group. This result demonstrated that the administration of feed containing tempe flour $10 \%$ was not significantly different from the administration of tempe flour $20 \%$ or soybean flour $10 \%$ in the number of osteoclasts produced. 
Table 3. The average number of osteoclasts per view

\begin{tabular}{lc}
\hline Treatment group & Number of osteoclasts \\
\hline Casein & $3.97 \pm 0.15^{\mathrm{c}}$ \\
Tempe flour $10 \%$ & $2.47 \pm 0.21^{\mathrm{b}}$ \\
Tempe flour 20\% & $2.33 \pm 0.11^{\mathrm{ab}}$ \\
Boiled soybean flour 10\% & $2.17 \pm 0.06^{\mathrm{ab}}$ \\
Boiled soybean flour $20 \%$ & $2.03 \pm 0.11^{\mathrm{a}}$ \\
\hline
\end{tabular}

Different letters in the same column show a very significant difference $(\mathrm{p}<0.01)$ based on Duncan's test

\section{Discussion}

Osteocytes are transitional cells from osteoblasts (Compton and Lee 2014). All bone cells in the adult skeleton are composed of 90-95\% osteocytes (Tresguerres et al. 2020). The sum of osteoblasts and osteocytes in Table 2 revealed that casein treated group had the significantly lowest $(\mathrm{p}<0.01)$ number of osteocytes and osteoblasts when compared to the other groups. Casein group was the control rat group which was given neither tempe flour nor boiled soybean flour var. Grobogan, only given casein. This result demonstrated that the treatments using feed containing tempe flour (10\% and $20 \%$ ) and boiled soybean flour (10\% and $20 \%$ ) could increase the number of osteoblasts and osteocytes in the tibia bone of rats.

Soybeans and tempe are foods that contain isoflavone and the minerals calcium, phosphorous, and magnesium which are needed for bone growth (Astawan et al. 2020b). Atmaca et al. (2008) reported that isoflavone from soybeans could be used for the management of post-menopause osteoporosis diets. Suarsana et al. (2011) reported that the administration of isoflavone-rich tempe flour in normal female rats could increase the calcium, phosphorous, and estrogen content in blood. Surplus calcium from blood is stored in bones and can be used in the process of bone modeling, remodeling, and to maintain bone density. Osteoblasts and osteocytes are one of the parameters of the bonemodeling process and bone density (Robling and Bonewald 2020).

Isoflavones are a sub-group of phytoestrogens that are able to bind with estrogen receptors (ERs) in the body (Pilsakova et al. 2010). Isoflavones in the form of genistein and daidzein are believed to bind with the receptor- $\beta$ in osteoblasts. This bond could cause an increase in protein-forming components, alkaline-phosphatase activity, and DNA-forming components in the osteoblast. The increased DNAforming components inside the osteoblast would increase the proliferation of the osteoblast. In addition, isoflavones can also increase the activity of alkaline-phosphatase which is the marker enzyme for osteoblast differentiation (Yamaguchi 2002). Molecular analysis showed that soybean isoflavone promote osteoblast proliferation and differentiation through Wnt3a/ $\beta$-catenin signal activation (Yu et al. 2015).

The results of the present study demonstrated that the administration of either tempe flour or boiled soybean flour var. Grobogan could increase the proliferation of osteoblasts and the differentiation of osteoblasts into osteocytes due to the presence of isoflavone compounds in these ingredients.

Tempe flour (10\% and 20\%) treated groups had very significantly higher $(\mathrm{p}<0.01)$ numbers of osteoblasts and osteocytes than those of boiled soybean flour (10\% and $20 \%$ ) treated groups. This showed that the administration of tempe flour could increase the number of osteoblasts and osteocytes more than the administration of boiled soybean flour. Tempe is a product made by fermenting soybeans using Rhizopus sp. This process causes a number of changes in the chemical compounds in the tempe, including the isoflavones. Some forms of isoflavones are glucoside, malonyl, and aglycone. The soybean fermentation process assisted by mold causes an incerase in isoflavone in the form of aglycone (Ferreira et al. 2011). Isoflavone in the form of aglycone is more lipid-soluble and easily able to absorb by the intestines and is the most active form (Hsiao et al. 2020). This is believed to be capable of increasing the isoflavone bonds in the osteoblast's receptor- $\beta$ for the proliferation and differentiation of the osteoblast. Moreover, the calcium content of tempe per $100 \mathrm{~g}$ dry weight is higher $(347 \mathrm{mg}$ ) than that of soybeans ( $254 \mathrm{mg}$ ) (Astawan et al. $2020 b$ ). Therefore, the administration of tempe flour from soybeans var. Grobogan could result in a higher number of osteoblasts and osteocytes than the administration of boiled soybean flour var. Grobogan.

The number of osteoblasts and osteocytes in tempe flour (10\%) group were very significantly lower $(p<0.01)$ than those of tempe flour $(20 \%)$ 
treated group. This demonstrated that the concentration of tempe flour had an effect on the increase in osteoblast and osteocyte numbers. Tempe flour $20 \%$ could increase the number of osteoblasts and osteocytes higher than tempe flour $10 \%$. This was because the minerals calcium, phosphorous, and magnesium, and the isoflavone contents were higher in tempe flour at a $20 \%$ concentration.

The numbers of osteoblasts and osteocytes of boiled soybean flour $10 \%$ treated group were not significantly different $(p>0.01)$ than those of boiled soybean flour $20 \%$ treated group. However, the two groups had a very significantly higher $(p<0.01)$ number of osteoblasts and osteoclasts than casein treated group. This demonstrated that the administration of boiled soybean flour var. Grobogan at both $10 \%$ and $20 \%$ could increase the numbers of osteoblasts and osteocytes higher than the administration of casein.

Soybeans and casein are materials that can be used as a source of protein. Soybeans are a source of plant-based protein, while casein is an animal-based protein source. Both contain very large amounts of protein. However, when consumed, high animalbased protein content would cause more calcium loss than would plant-based protein. Consumption of large amounts of plant-based protein is useful in preventing the excretion of calcium (Astawan et al. 2020b). The availability of calcium in the body is very important for the formation of bone mass. Therefore, the administration of boiled soybean flour var. Grobogan either $10 \%$ or $20 \%$ demonstrated better results in increasing the number of osteoblasts and osteocytes than casein.

An osteoclast is a multinuclear cell that originates from the monocyte-macrophage lineage. This cell is responsible for bone resorption. The activity of osteoclasts is closely related to the activity of osteoblasts (formation of new bone tissue) (Bhattarai et al. 2020). These two cells interact in the bone remodeling process. A number of hormones, cytokines, and growth factors are the most important factors in this process. Estrogen is an important hormone that influences the activity and function of both osteoblasts and osteoclasts (Kalkan and Tulay 2018). Estrogen's main function is to suppress the life span and induce osteoclasts to undergo apoptosis (Soysa et al. 2012).
The numbers of osteoclasts in rats given tempe flour and boiled soybean flour were fewer than in the group of rats given casein. This was because of the isoflavone content in tempe and soybean. Isoflavone is an estrogen-like compound (Pilsakova et al. 2010). The activity of osteoclasts is controlled by phosphorylation of a cell membrane constituent which involves tyrosine kinase. It has been reported that genistein (a form of isoflavone) is an inhibitor of tyrosine kinase (Atmaca et al. 2008). In the present study, the isoflavone compound in tempe flour and boiled soybean flour var. Grobogan could also suppress the number and activity of osteoclasts. Sabri (2011) reported that isoflavone from veld grape stalks (Cissus quadrangula) could decrease the number of osteoclasts in female rat osteoporosis models that had undergone ovariohysterectomy. Wiyasa et al. (2008) stated that the isoflavone from kudzu (Pueraria lobata) extract could decrease the number of osteoclasts in rats that had undergone ovariectomy. Darmadi et al. (2011) reported that isoflavone from cowpea extract could also suppress the number of osteoclasts in rats that had undergone ovariectomy.

The numbers of osteoblasts and osteoclasts in casein treated group (Tables 2 and 3 ) have a negative correlation. The number of osteoblasts in casein treated group was the smallest compared to all the other groups, but casein group had greatest number of osteoclasts. Phan et al. (2004) and Atmaca et al. (2008) stated that the activity of osteoclasts is regulated by the presence of osteoblasts. Osteoblasts produce osteoprotegerin (OPG) which is an osteoclast inhibitory factor (OCIF) (Phan et al. 2004). This caused the negative correlation between the number of osteoblasts and the number of osteoclasts in casein treated group.

The number of osteoclasts that could be found and counted in every group was few. According to the reports by Blair and Athanasou (2004), osteoclasts are rarely found in normal mature bones, but often found in bones that have pathological abnormalities such as osteoporosis. Based on these reports, it is believed that the experiment rats' bones were still normal and had not experienced any abnormalities. A study by Sengupta (2013) reported the comparison between laboratory rats and humans. Data from the aforementioned study stated that at 13.2 days 
old, a laboratory rat would be equivalent to a oneyear-old human in age. The rats in the present study were approximately 120 days old ( 30 days old at the beginning of the experiment plus 90 days during the experiment), meaning that the rats would be equivalent to 10 -year-old humans in age. This shows that the experiment rats were still within their growing stage and were far from the age when osteoporosis usually strikes.

In the event of osteoporosis, especially postmenopause, the hormone estrogen which plays a role in bone metabolism would decrease. The lack of estrogen would increase the level of tumor necrosis factor $\beta$ (TNF- $\beta$ ). Tumor necrosis factor $\beta$ (TNF- $\beta$ ) is a cytokine compound that is involved in bone resorption. Therefore, in the event of osteoporosis, the number of osteoclasts would rise due to the increased bone resorption activity (Blair and Athanasou 2004).

The numbers of osteoclasts in tempe flour $10 \%$ and $20 \%$ treated groups were not significantly different $(p>0.01)$. The numbers of osteoclasts in boiled soybean flour $10 \%$ and $20 \%$ groups were also not significantly different. The number of osteoclasts in tempe flour $10 \%$ treated group was not significantly different $(p>0.01)$ from those in tempe flour $20 \%$ and boiled soybean flour $10 \%$ groups. The number of osteoclasts in tempe flour $20 \%$ group was also not significantly different $(\mathrm{p}>0.01)$ from those in boiled soybean flour $10 \%$ and $20 \%$ groups. However, the numbers of osteoclasts in all the aforementioned groups were significantly lower $(\mathrm{p}<0.01)$ than casein group. These results show that the administration of either tempe flour (10\% and $20 \%$ ) or boiled soybean flour var. Grobogan (10\% and 20\%) were both beneficial in suppressing the number of osteoclasts compared to the administration of casein.

According to a report by $\mathrm{He}$ and Che (2013), the genistein content in American soybean flour was higher $(85.12 \mathrm{mg} / 100 \mathrm{~g})$ than that of tempe made from American soybeans (36.15 mg/100 g). In contrast, Safrida (2012) reported that the genistein content of tempe flour made from imported soybeans (var. Americana) was higher (250.65 $\mathrm{mg} / \mathrm{kg}$ ) than that of imported soybean flour (var. Americana) (65.15 mg/kg). Puspitasari et al. (2020) also stated that the genistein content of tempe made from local soybeans was higher $(4.94 \mathrm{mg} / 100 \mathrm{~g}$ ) than that of local soybeans ( $1.60 \mathrm{mg} / 100 \mathrm{~g})$. Genistein is a form of isoflavone which is believed to have the ability to affect the activity of osteoclasts. In the present study, the results demonstrated that the administration of feed containing either tempe flour or soybean flour var. Grobogan could reduce the number of osteoclasts. The difference in genistein content in tempe flour and soybean flour could be caused by differences in the soybean variety, the conditions where the soybeans were planted, and the processes and methods employed by each study.

\section{Conclusion}

The administration of tempe flour and soybean flour var. Grobogan could increase the numbers of osteoblasts and osteocytes in the tibia of laboratory rats. The administration of tempe flour increased the numbers of osteoblasts and osteocytes better than soybean flour. The administration of tempe flour 20\% resulted in higher osteoblast and osteocyte numbers than the administration of tempe flour $10 \%$. Moreover, the administration of tempe flour $(10 \%$ and $20 \%$ ) or boiled soybean flour var. Grobogan ( $10 \%$ and $20 \%$ ) could decrease the number of osteoclasts.

\section{Acknowledgements}

This study was supported by Directorate of Research and Community Service, the Directorate General of Higher Education, Ministry of Research, Technology and Higher Education, Republic of Indonesia through "Penelitian Dasar Unggulan Perguruan Tinggi 2019" and "Penelitian Berbasis Kompetensi 2019" schemes onbehalf Made Astawan.

\section{References}

[AOAC] Association of Official Analytical Chemistry. 1995. Official Method of Analysis. Gaithersburg (US): AOAC. Astawan M et al. 2020a. Equivalence test between the physicochemical properties of transgenic and nontransgenic soy flour. J Nutr Sci Vitaminol 66:286-294.

Astawan M et al. 2020b. Calcium bioavailability of tempe and boiled soybean flours and its effect on osfemurs in experimental rats. J Nutr Sci Vitaminol 66:314-319.

Astawan M et al. 2020c. Comparison between the potential of tempe flour made from germinated and nongerminated soybeans in preventing diabetes mellitus. Hayati 27: 7-23.

Atmaca A et al. 2008. Soy isoflavones in the management of postmenopausal osteoporosis. Menopause 15:748757.

Bhattarai HK et al. 2020. Vitamin D, calcium, parathyroid hormone, and sex steroids in bone health and effects of aging. J Osteoporos 2020:1-10. 
Blair HC, Athanasou NA. 2004. Review: recent advances in osteoclast biology and pathological bone resorption. Histol Histopatho 19:189-199.

Compton JT, Lee FY. 2014. A review of osteocyte function and the emerging importance of sclerostin. J Bone Joint Surg Am 96:1659-1668.

Darmadi D et al. 2011. The effect of cowpeas on the osteoblasts and osteoclasts of rats with ovariectomy. JKB 26:151 155.

Ferreira MP et al. 2011. Changes in the isoflavone profile and in the chemical composition of tempeh during processing and refrigeration. Pesqui Agropecu Bras 46:1555-1561.

He FJ, Chen JQ. 2013. Consumption of soybean, soy foods, soy isoflavones and breast cancer incidence: differences between Chinese women and women in Western countries and possible mechanisms. Food Sci Hum Well 2:146-161.

Hsiao YH et al. 2020. Bioavailability and health benefits of major isoflavone aglycones and their metabolites. $J$ Funct Foods 74:104164.

Kadar AD et al. 2020. Metabolomics based study of the effect of raw materials to the end product of tempe-an Indonesian fermented soybean. Metabolites 10:1-11.

Kalkan R, Tulay P. 2018. The interactions between bone remodelling, estrogen hormone and EPH family genes. Crit Rev Eukaryot Gene Expr 28:135-138.

Neve A et al. 2010. Review: osteoblast physiology in normal and pathological conditions. Cell Tissue Res 343:289302 .

Phan TCA et al. 2004. Review: interaction between osteoblast and osteoclast: impact in bone disease. Histol Histopathol 19:1325-1344.

Pilsakova L et al. 2010. The physiological actions of isoflavone phytoestrogens. Physiol Res 59:651-664.

Puspitasari A et al. 2020. The effect of soybeans germination on proximate composition and isoflavones bioactive components of fresh and semangit tempe. Jurnal Pangan 29:25-34.
Puteri NE et al. 2018. Chacterization of biochemical and functional properties of water-soluble tempe flour. $J$ Food Sci Technol 38:147-153.

Rachmawati N et al. 2021. Haematological and biochemical serum profiles of experimental rats fed with GMO and non-GMO soybean. J Gizi Pangan:167-176.

Robling AG, Bonewald LF. 2020. The osteocyte: new insights. Annu Rev Physiol 82:485-506.

Sabri M. 2011. Activity of ethanol extract of veld grape stalk (Cissus quadrangula Salisb) as an antiosteoporosis in rats (Rattus norvegicus) [Dissertation]. Bogor, indonesia: Bogor Agricutural University.

Safrida. 2012. Comparison of bioactive compounds content of aglycone isoflavones in soy powder and tempeh powder. In: Proceeding. Food Sovereignty and Natural Resources in Archipelago Region. Bogor: PERMAMA and IPB. pp. 1-6.

Sengupta P. 2013. The laboratory rat: relating its age with human's. Int J Prev Med 4:624-630.

Soysa NS et al. 2012. Review: osteoclast formation and differentiation. I Med Dent Sci 59:65-74.

Suarsana IN et al. 2011. Isoflavone-rich tempe flour increases the calcium, phosphorous, and estrogen plasma levels of normal female rats. J Veteriner 12:229-234.

Tresguerres FG et al. 2020. The osteocyte: a multifunctional cell within the bone. Ann Anat 227:151422.

Wiyasa IWA et al. 2008. The effect of the isoflavones genistein and daidzein from kudzu (Pueraria lobata) strain Kangean extract on the numbers of osteoblasts and osteoclasts of hypoestrogenic Rattus norvegicus Wistar. Majalah Obstet Ginekol Indones 32:148-152.

Yamaguchi M. 2002. Isoflavone and bone metabolism: its cellular mechanism and preventive role in bone loss. J Health Sci 48:209-222.

Yu F et al. 2015. Soybean isoflavone treatment induces osteoblast differentiation and proliferation by regulating analysis of $\mathrm{Wnt} / \beta$-catenin pathway. Gene 573:273-277. 